\title{
Application of 13\% Derivation Fund in Akwa Ibom State: Matters Arising
}

\author{
Sofiri Joab-Peterside \\ Department of Sociology, University of Port Harcourt, Rivers State, Nigeria \\ Emmanuel Nwakanma \\ Department of Sociology, University of Port Harcourt, Rivers State, Nigeria
}

\begin{abstract}
At the inception of the current democratic regime in 1999, non-implementation of $13 \%$ derivation formula was a source of much agitations which metamorphosed from minor unorganized hostilities to highly sophisticated cocktail of militant organizations, and criminal gangs which fed on agitations for fair play in development of the region which metamorphosed from minor unorganized hostilities to highly sophisticated cocktail of militant organizations, bringing governors of the Niger Delta states into closer alliance in quest for better existential conditions for their people. Against the backdrop of the activities of the kleptomaniac governing elites, it appears that allocating more money to the States may not be a guarantee that the funds will be used for the purpose for which they were appropriated. Consequently, the establishment of an institution charged solely with the responsibility of applying the derivation funds to address the nagging developmental needs of the inhabitants of the oil producing communities in the state is recommended.
\end{abstract}

Keywords: 13 Percent derivation fund, Oil bearing communities, Niger Delta, Akwa Ibom, and Development DOI: $10.7176 / \mathrm{DCS} / 10-10-06$

Publication date:October $31^{\text {st }} 2020$

\section{Background to the study}

Akwa Ibom State is the tenth largest State in Nigeria in terms of landmass. Its $129 \mathrm{~km}$ coastline is not only the longest in the country, it is also a very rich source of a wide variety of fishes and sea foods including catfish, barracuda, blue marlin, squid, sardine, croakers, shrimps, prawns, crayfish, snappers, bivalves and oysters. The State is host to Mobil Producing Unlimited, a subsidiary of ExxonMobil Limited. The State capital is Uyo and there exist three Senatorial Districts and ten Federal Constituencies. Akwa Ibom State's population density is put at 333. $/ \mathrm{km}^{2}$ (863.1/sq.ml), with a GDP of \$11.18 billion and per capita of \$2.779 (Birkhoff, 2007). The State in 2016 kept the record of the highest oil and gas producing state in Nigeria. The people are predominantly of the Christian faith. The major ethnic groups are Ibibio, Annang and Oron. Other ethnic groups include Eket, Ibeno, Obolo/Andoni and Efik.

The state is endowed with arable land which can produce enough food for the people, as well as cash crops for export such as oil palm, raffia palm, yam, cocoyam and plantain. Equally, the state's sea and inland waters are rich in sea food such as assorted fish, shrimps, prawns, and shell fish. The State's traditional wine comes from the raffia palm and oil palm. The deposits of mineral resources include crude oil, petroleum, gas and crude salt. Akwa Ibom people are noted for pottery and raffia produce, all of which have added new dimensions to the economy and life of the people. The State falls within the tropical zone with a dominant vegetation of green foliage of trees and shrubs. It constitutes a major chunk of the nation's oil-palm belt. The Atlantic coastline stretches $129 \mathrm{~km}$ from Oron in the East to Ikot Abasi in the West. The State also has three distinct vegetation zones: the saline water swamp forest, the fresh water swamp forest and the rain forest. It is also among the largest states that produces oil (crude oil). The State also has an airport and two major seaports on the Atlantic Ocean.

\section{The Problem}

At the inception of the current democratic regime in 1999, non-implementation of $13 \%$ derivation formula was a source of much agitation, bringing the governors of the region into closer alliance with the resource control agitators and into conflict with the federal authorities. The sad paradox is that wealth generates poverty in the Niger Delta States: the fact that enormous wealth from the region had existed side-by-side extremely poor communities. This impoverishment has gone hand in hand with massive destruction of the fragile ecosystem of the region, further destroying livelihoods. Among the people of the area, there is a stand point that favours giving more resources to the state and local governments. Given the level of corruption in the space of "high politics" and the unaccountability of the governing elite at both the state and local government levels, giving more money to the states and local governments may not be a guarantee that such money will reach people for whom it is meant for. Nearly 20 years of democratic rule, there is hardly any state in the region that has been transformed in concrete terms. On a daily basis the governed are being confronted about sleaze in which those who claimed to be their governors are ensnared. The challenge of the Akwa Ibom State, like any other state in the Niger Delta is about 
understanding the relation between affluence and affliction: wealth generates poverty in the states because the enormous wealth from the Niger Delta (including the 13\% derivation fund) has existed side-by-side extremely poor communities.

Akwa Ibom state is located in the oil rich Niger Delta which suffers severe deprivation in the hands of the Federal ruling class. Despite its contribution to Nigeria's economic growth, the region's Human Development Index (HDI) score was a low value of 0.564 in 2005(NDHR, 2006). Although these ratings put the Niger Delta at a slightly higher level than Nigeria's overall HDI of 0.453 at the same period, the region rated far below countries or regions with similar oil and gas resources. For instance, the HDI for Saudi Arabia in 2000 stood at 0.800, while in 2003 the United Arab Emirates, Kuwait, Libya, Venezuela and Indonesia achieved scores of 0.849, 0.844, 0.772 and 0.697 respectively (UNDP, 2006; BRACED Commission, 2012). Human per capita income is very low confirming the alarming rate of poverty in the region. Other human development indicators such as life expectancy, maternal and child health, access to education and quality health care services as well as overall wellbeing of the inhabitants is steadily on the reverse, due to abysmal neglect over the years. The composite employment data which are conservative due to inadequate documentation showed that the rate of unemployment surged from $14.0 \%$ in 2007 to $19.7 \%$ at the end of December 2009 and thence to $21.1 \%$ by December 2010 . The unemployment rate has for some time been higher in rural communities than in cities for all age groups. For example, unemployment rate amongst 18-24 age groups was said to be higher in 2006 at 30\%. Another age group highly affected is $25-44$, about $88 \%$ in 2006 (NDDC Master Plan, 2001).

The evaluation of the revenue receipts of oil-producing states, particularly, Akwa Ibom since 2000 indicates that 13 per cent derivation formed the lion share of their earnings during the period under review (Ebiri, 2019). In fact, except for the brief period of lower oil prices in late 2006 and a greater part of 2009, allocations to oil producing states in the Niger Delta steadily skyrocketed up to mid-2014. NEITI Fiscal Allocation and Statutory Disbursement 2012-2016 Audit showed that Akwa Ibom State received 1, 133,163,123,295.11 an increase of 16.5\% (NEITI, 2019). In a related development, available data from NEITI, Federation Account Allocation Committee, and the National Bureau of Statistics(NBS) revealed that between 2000 and 2018, Akwa Ibom State received over $\mathrm{N} 2,637,953,892,850 \mathrm{t}$, The $13 \%$ derivation fund is the financial incentive enshrined in the constitution to be distributed to oil producing communities, based on the production input to serve as benefits and encourage the communities to create enabling environment for more production of cure oil and gas (NEITI, 2019).

The drop in the price of crude oil at the global market and the economic recession in Nigeria affected the nation's oil and gas industry in 2016. With the significant drop in global oil price due to the increased production of shale oil in the US, revenue that accrued to the government fell short of the amount projected for the same period. Consequently, the government, both federal and state, resorted to borrowing to fill the revenue gap. However, by the third quarter of 2017, Nigeria oil and gas had gained tractions with growth of up to $26 \%$ (yearon-year); contributing up to $10 \%$ of total real GDP in the third quarter of 2017 . The significant increase in crude oil price from $\$ 38$ in early 2017 to $\$ 56$ by the third quarter of 2017 was a great relief to the Nigeria government. According to OPEC (2008, Annual Statistical Bulletin and National Bureau of Statistics (NBS), of 2016, crude oil price for 2017 averaged $\$ 52.43$ per barrel, which was a gain upon Nigeria's benchmark price of $\$ 44.50$ per barrel used for public budgeting in the same year. This created optimism in the states, especially in a state like Akwa Ibom that was, in 2016, unable to pay her workers. The sad paradox is while oil money continues to flow into the coffers of these states, most oil bearing communities remain poverty-stricken, plagued by unemployment, and devoid of basic social amenities like portable water, hospitals, electricity, motor able roads, and conducive environment in their schools all of which increased the level of frustration and dissatisfaction in the region (Ebiri, 2019).

It is a popularly held belief among the inhabitants of state that one severe deprivation which the people have persistently suffered in the hands of the Federal government, which has led to restiveness and instability in the area, has been the progressive erosion, through the years of the principle of revenue sharing and fiscal federalism. This deprivation is at the centre of all agitations in the Niger Delta states for resource control. It was reasoned that restitution for fiscal Federalism will provide restitution for all the core issues in the Niger Delta. Fiscal federalism simply means that states, the component units of the federating entity which are directly endowed with the resources within their territories should have fair share of the benefits, revenue, royalty, taxes etc. Derivable from such endowments while contributing equitably to the upkeep of the central/federal government (Ibibio Ethnic Nationality, 2008). Hence, one of the key measures for addressing the Niger Delta question is review of the Federation Account sharing arrangement in order to allocate more funds for the development of the region. It is against this backdrop that statutory allocation to the oil producing areas was increased from $1 \%$ to $13 \%$. Furthermore, the statutory allocation for the amelioration of ecological problems throughout the Federation, from which states in the region are expected to benefit, was increased from 1\% to 2\% of the Federation Account in 1992 (NIM, 2008).

The principle of derivation contained as a proviso to Section 162(2) of the 1999 Constitution is the only constitutional provision that acknowledges ownership of resources as a basis for revenue allocation. The principle 
is that for the purpose of Revenue Allocation, a certain percentage of revenue derived from any resource should be given to the state from, which such resource is derived. Although Akwa Ibom State is one of the leading oil producing states in the Niger Delta, her tremendous potential for economic growth and sustainable development remains unfulfilled and its future threatened by deteriorating economic conditions that are not being addressed by present policies and actions. Not surprising, the questions begging for answer is how Akwa Ibom State had utilized the alleged insufficient past allocations to addressing the development needs of her citizens. The development problematic is about understanding the relation between affluence and affliction: wealth generates poverty in the state because the enormous wealth from oil has existed side-by-side extremely poor communities.

\section{Objectives of the Study}

(i) To examine the performance of State Governments in terms delivery of development to inhabitants of the Oil and Gas Producing Areas

(ii) Investigate the level of understanding and uses of derivation fund

(iii) To examine the extent to which people of the oil and Gas producing Areas have benefited from the derivation fund

(iv) To examine Institutions established by State Governments for the sole purpose of managing the derivation fund

(v) Examine the peoples' view on how make governance of derivation resource space transparent and accountable to the people of Oil and Gas Producing Areas.

\section{Method of the Study}

The study was conducted in two Local Government Areas of Akwa Ibom State namely Uyo and Ibeno. The communities sampled in the State are Uko, Offot, Ukpenekang, Iwokpom Obolom and Iwu Okpom Obolom. Fifty respondents were sampled from each Local Government Area (LGA) making the sample size One Hundred (100) respondents. In addition, two Focus Group Discussions (FGDs) involving Thirty (30) conveniently selected participants from communities in the two Local Government Areas were also conducted to elicit supplementary qualitative information on the subject of interest. The FGDs was guided by an inventory guide to ensure uniformity of responses elicited from respondents and special consideration was taken to ensure that diverse elements of the population of selected communities were represented. Methodology Workshop/Report Writing meetings were organized to train field enumerators on the study's underlying philosophical framework, creation of rapport in the field and administration of the questionnaire as well as conduct of pre-test to ascertain the validity of the instrument; while the report writing meetings considered and agreed on a report writing framework for the preliminary and final reports.

The data was essentially derived from primary and secondary sources. The primary data emanated from questionnaire instrument which was carefully developed along thematic areas or focus of the study was administered One Hundred (100) respondents drawn equally from each of the Two Local Government Areas and communities carefully chosen to ensure all geographical and ethno-linguistic groups in the State were represented. Enumerators who were selected from the study's locale are proficient in the local language, familiar with the socioeconomic and political profiles of the communities. This facilitated a generally and relatively hitch free administration of the questionnaire. Field data gathering activities commenced on the $18^{\text {th }}$ April and ended on the $23^{\text {rd }}$ of May, 2019.

To augment data from primary sources, the research team embarked on a vigorous acquisition of relevant literatures and materials to establish baseline information on the indicators and assessment criteria for good governance. To this end, the processes of review of relevant literature include: the acquisition and review of relevant literatures in line with the objectives of the study, establishment of baseline information on socioeconomic, cultural environment, resource utilization and development, accountability, transparency, and participatory management of oil revenue. On completion of field data collection, the research team developed a code book and thereafter commenced data entering into SPSS data base. The findings are presented in charts and tables. We also used historical (secondary) data to reinforce the primary data. Historical events are more convincing if properly demonstrated. This is what our method of analysis tended to emphasize.

A major limitation of the study is that it took more time for enumerators to interview all the respondents. This is because some respondents were out at the time of calling, but were contacted by recalling while others though in, found the time inconvenient and so on such respondents a call back was made at another time. Furthermore, the heavy rainy season slowed down the speed of movement from one community to another since the enumerators relied on motorbikes and bicycles as major means of transportation. The high level of illiteracy was another problem. Consequently, the interviewers have to spend more time on individual respondent translating questions from English to Pidgin English or and local languages where some respondents do not understand even Pidgin English. It was also difficult to access relevant government documents/publications especially those on disbursement of $13 \%$ derivation fund due in part, to unnecessary bureaucracy and suspicion by government 
officials of intention of researchers.

\section{Analytical Frame Work}

Anglo-American political theory uses the term "government" to refer to the formal institutions of the state and their monopoly of legitimate coercive power. Hence government is characterized its ability to enforce them. In agreement with this view, Stoker (1998) argues that government is understood to refer to the formal and institutional processes which operate at the level of the nation state to maintain public order and facilitate collective action. However, the growing theoretical work on governance has resulted in redirection of the use and import of the concept of "government". Governance signifies a change in the meaning of government, referring to a new process of governing; or a changed condition of ordered rule; or a new method by which society is governed (Rhodes, 1996; Stoker, 1998).

The point needing stress is that governance is ultimately concerned with creating the conditions for ordered rule and collective action. The outputs of governance are not therefore different from those of government. It is a rather a matter of a difference in processes. The governance perspective also draws attention to the increased involvement of the private and voluntary sectors in service delivery and strategic decision making. Consequently, responsibilities that were previously the near exclusive responsibility of government have been shared. Contracting -out and public-private partnerships are now part of the reality of public services and decision-making in the state.

The Governance perspective demands that these voluntary sector organizations be recognized for the scale and scope of their contribution to tackling collective concerns without reliance on the formal resources of the government. Responsibilities have also been taken up by the private sector as well as not- for-profit organizations. Governance as an interactive process involves various forms of partnership. Governance is the act of governing. It relates to decision that define expectations, grant power, or verify performance. It consists of either a separate process or part of decision making or leadership processes. In modern nation-states, these processes and systems are typically administered by structures, agencies and institutions at different levels of government; as such, when discussing or evaluating governance in particular organizations or government, the quality of governance within the structure of government is often compared to standards of good governance. We may distinguish the term governance from government; "governance" is what a "governing body" does. It might be a geo-political entity (nation state), a corporate entity (business entity), a socio-political entity (Chiefdom tribe, family) etc, or any number of different kinds of governing bodies, but governance is the way rules are set and implemented.

There is no single and exhaustible definition of "good governance" nor is there a delimitation of its scope, which commands universal acceptance. The term is used with great flexibility, even though this poses some default at the operational level. In a nutshell, good governance relates to political and institutional processes and outcomes that are deemed necessary to achieve the goods of development. It is a process whereby public institutions conduct public affairs, manage public resources and guarantee the realization of human rights in a manner essentially free of abuse and corruption, and with regard for the rule of law. The true test of good governance is the degree to which it delivers on the promise of effectively guaranteeing the citizens' right to quality health care service, adequate housing, sufficient food, quality education, justice, equity and personal security. Governance is a broad concept, for our purpose, the study aligns with the view of Wohlmut (1999) who submits that good governance pertains to the key issues of democracy, development, popular participation, transparency, accountability, responsiveness to public needs and improving the capacity of government agencies to deliver public services, and how to improve the quality and efficiency of public administration and the civil service.

\section{Findings of the Study}

Akwa Ibom State received the highest total Mineral Revenue of N873.589 billion from 2012-2016 from 20122016(NEITI, 2019). As the State that received the highest share of federal allocations in 2016, based on the payment of $13 \%$ of petroleum revenues to States of derivation, Akwa Ibom has acquired a tradition of embarking on expensive prestige projects with no apparent benefit for its poor inhabitants. According to NEITI, Akwa Ibom state received the sum of N143.6 billion in 2017 from the Federation Account, reflective of improved global crude oil prices. The inability of the State to develop and generate revenue within the State economic prowess exposed it to internal and external loans. As the statutory receipts could not finance the entire budget, the government of Akwa Ibom continued to take opaque loans during the year. As in other states, the political processes seemed to be skewed in favour of entrenched political interests.

Table 1: Gender of Respondents

\begin{tabular}{llrrrr}
\hline \hline Valid & & Frequency & Percent & Valid Percent & Cumulative Percent \\
& Male & 63 & 63.0 & 63.0 & 63.0 \\
& Female & 37 & 37.0 & 37.0 & 100.0 \\
& Total & 100 & 100.0 & 100.0 & \\
\hline \hline
\end{tabular}

Source: Field Survey April, 2019 
The study was conducted in two Local Government Areas of Akwa Ibom State namely Uyo and Ibeno. The communities sampled are Uko, Offot, Ukpenekang, Iwokpom Obolom and Iwu Okpom Obolom. Fifty respondents were sampled from each Local Government Area making the sample size One Hundred (100) respondents. Although efforts were made to achieve gender parity in selection of respondents, data at the disposal of the study showed that 63 or $63.0 \%$ of respondents are male while 37 or $37.0 \%$ other respondents are female. Given the nature of the rural economy, the women were either away to the farm or market; hence it was difficult to meet most of them at home in course of the study. Table 1 above and graphical distribution shown in Figure 1 below presents the gender distribution of the respondents.

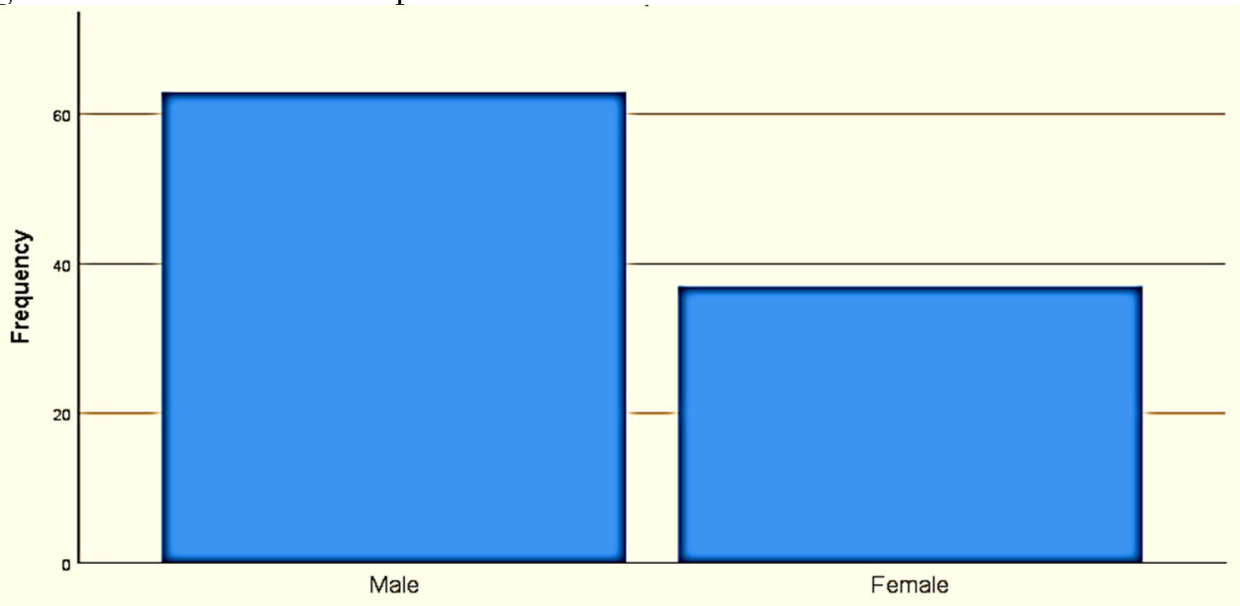

Figure 1: Bar Chart Showing Gender Distribution of Respondents

Table 2 shows that 40 or $40.0 \%$ of the respondents fall within the age range of 18 to less than 35 years, another 54 or $54.0 \%$ of the respondents are 35 to less than 65 years, while 5 or $5 \%$ other respondents are 65 years and above. This implies that the study captured the active population of the study area who are experienced enough to answer the questions contained in research instrument.

Table 2: Age Distribution of Respondents

\begin{tabular}{llrrrr}
\hline \hline & Frequency & Percent & Valid Percent & Cumulative Percent \\
\hline Valid & Less than 18 years & 1 & 1.0 & 1.0 & 1.0 \\
& 18 to less than 35 years & 40 & 40.0 & 40.0 & 41.0 \\
35 to less than 65 years & 54 & 54.0 & 54.0 & 95.0 \\
65 and above years & 5 & 5.0 & 5.0 & 100.0 \\
Total & 100 & 100.0 & 100.0 & \\
\hline \hline
\end{tabular}

Source: Field Survey, April 2019

Data in Figure 2 shows that 2 or $2.0 \%$ of respondents attended no school at all, 9 or $9.0 \%$ of respondents indicated they had some form of primary education, 7 or $7.0 \%$ of respondents stated that they completed primary education. Another 26 or $26 \%$ of the respondents claimed the completed secondary education while as high as 55 or $55 \%$ of the respondents claimed they were educated above secondary level. The level of educational attainment contributed to the success of the field work as the respondents were eager to participate in the study.

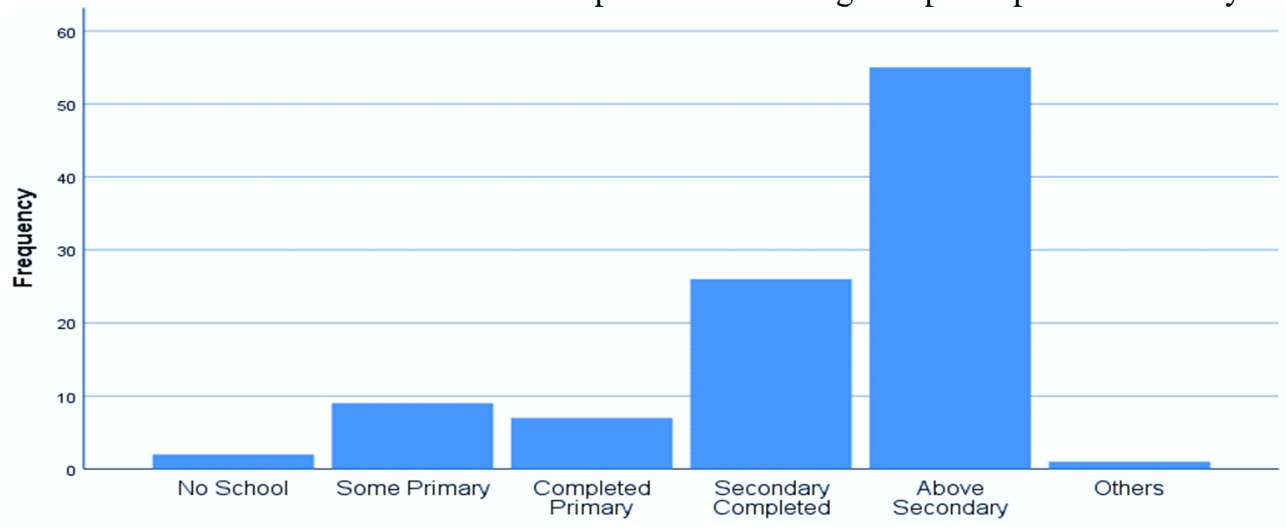

Figure 2: Bar Chart Showing Educational Attainment Distribution of Respondents 
Table 3: Marital Status of Respondent

\begin{tabular}{llrrrr}
\hline \hline & & Frequency & Percent & Valid Percent & Cumulative Percent \\
\hline Valid & Single & 51 & 51.0 & 51.0 & 51.0 \\
& Married & 49 & 49.0 & 49.0 & 100.0 \\
& Total & 100 & 100.0 & 100.0 & \\
\hline \hline
\end{tabular}

Source: Field Survey, April 2019

With respect to marital status, 51 or $51.0 \%$ of respondents stated that they are single while another 49 or $49.0 \%$ of the respondents claimed they are married. The study revealed that the major housing arrangements of the study area are rented apartment, bungalow and traditional housing types especially in the rural areas. Data on table 3 above and graphical distribution shown in Figure 3 below underscores this fact.

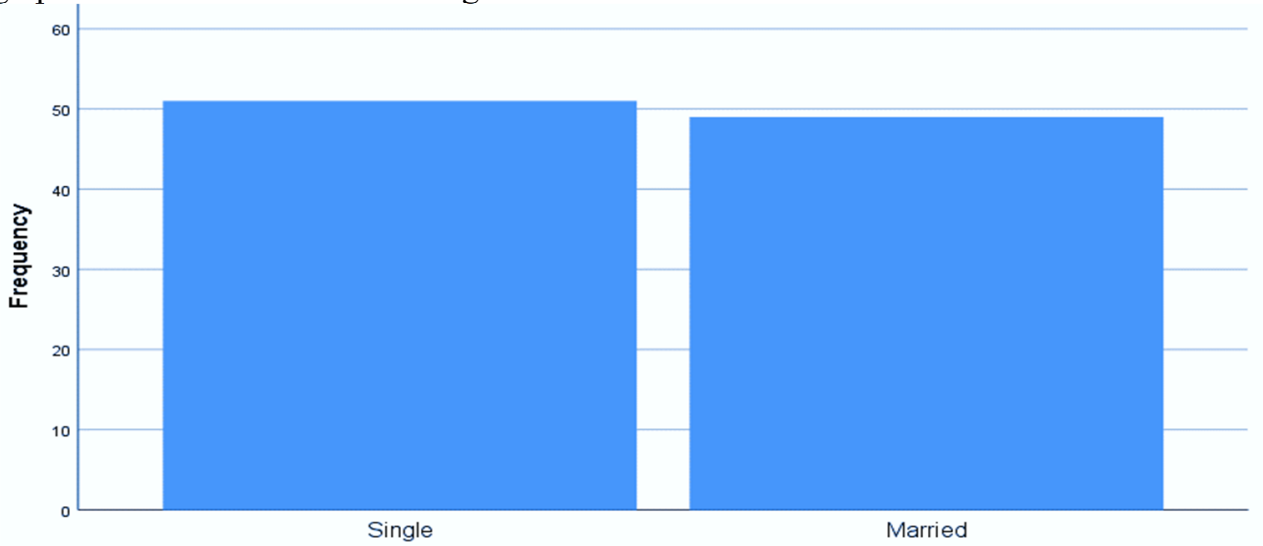

Figure 3: Bar Chart Showing Marital Status Distribution of Respondents

Table 4: Housing Arrangement

\begin{tabular}{llrrrr}
\hline \hline & & Frequency & Percent & Valid Percent & Cumulative Percent \\
\hline Valid & Traditional & 16 & 16.0 & 16.0 & 16.0 \\
& Rented Apartment & 34 & 34.0 & 34.0 & 50.0 \\
& Bungalow & 26 & 26.0 & 26.0 & 76.0 \\
Sharing a Room with Friend & 8 & 8.0 & 8.0 & 84.0 \\
Duplex & 3 & 3.0 & 3.0 & 87.0 \\
Others & 13 & 13.0 & 13.0 & 100.0 \\
Total & 100 & 100.0 & 100.0 & \\
\hline \hline
\end{tabular}

Source: Field Survey, April 2019

As shown in Table 4, 34 or $34.0 \%$ of respondents stated that they live in rented apartment; 26 or $26.0 \%$ other respondents stated that they live in bungalow, another 16 or $16.0 \%$ of respondents indicated they live in traditional housing type; 8 or $8.0 \%$ of respondents claimed they share rooms with their friends. 3 or $3.0 \%$ and 13 or $13.0 \%$ the respondents stated that they live Duplex and other forms of housing arrangement respectively. The traditional housing and bungalow housing types are the predominant housing arrangements in the rural areas, while the rented apartment and duplex are common in Uyo the State capital. Room sharing arrangement with a friend is common among the young people and this housing type is spread among communities in the study area.

With respect to the profession of respondents, facts at the disposal of the study show that 24 or $24.0 \%$ of the respondents are self -employed in trade, 15 or $15.0 \%$ are students, 14 or $14.0 \%$ of the respondents are engaged in farming/fishing while 11 or $11.0 \%$ other respondents are private sector employees. Most of those who claimed they are engaged in farming/fishing are resident in Ibeno which to a large extent is a fishing community. 7 or $7.0 \%$ of the respondents are civil servants (both State and Local Government Council employees); other 6 or $6.0 \%$ o of respondents stated they are contractors. 11 or $11.0 \%$ of respondents claimed they are unemployed; another 2 or $2.0 \%$ of respondents are engaged in unpaid work, 1 or $1.0 \%$ of the respondents have no profession while other 9 or $9.0 \%$ of respondents are engaged in other forms of business which they could not categorize. Data on Table 5 above below underscores this fact. 
Table 5: Profession of Respondents

\begin{tabular}{|c|c|c|c|c|c|}
\hline & & Frequency & Percent & Valid Percent & Cumulative Percent \\
\hline \multirow[t]{11}{*}{ Valid } & No Profession & 1 & 1.0 & 1.0 & 1.0 \\
\hline & Civil Servant & 7 & 7.0 & 7.0 & 8.0 \\
\hline & Private Sector Employee & 11 & 11.0 & 11.0 & 19.0 \\
\hline & Farming/ Fishing & 14 & 14.0 & 14.0 & 33.0 \\
\hline & Contractor & 6 & 6.0 & 6.0 & 39.0 \\
\hline & Self Employed in Trade & 24 & 24.0 & 24.0 & 63.0 \\
\hline & Student & 15 & 15.0 & 15.0 & 78.0 \\
\hline & Unemployed & 11 & 11.0 & 11.0 & 89.0 \\
\hline & Unpaid Worker & 2 & 2.0 & 2.0 & 91.0 \\
\hline & Others & 9 & 9.0 & 9.0 & 100.0 \\
\hline & Total & 100 & 100.0 & 100.0 & \\
\hline
\end{tabular}

Source: Field Survey April, 2019

It is therefore not a surprise that as high as 89 or $89.0 \%$ of the respondents stated that they have dependants. Of the entire respondents, 31 or $31.0 \%$ of respondents stated that they have secondary source of income, while 69 or $69.0 \%$ other respondents indicated they do not. Furthermore, 22 or $22.0 \%$ of those respondents who stated that they have secondary source of income indicated that they are involved in occasional business; 3 or $3.0 \%$ and 1 or $1.0 \%$ of respondents stated that they benefit from personal and occasional transfer respectively. This information is important for this study as it reveals the economic status of respondents in the selected communities and how they cope with their living conditions (See Table 6).

Table 6: Respondent with Secondary Source of Income

\begin{tabular}{llrrrr}
\hline \hline & & Frequency & Percent & Valid Percent & Cumulative Percent \\
\hline Valid & Yes & 31 & 31.0 & 31.0 & 31.0 \\
& No & 69 & 69.0 & 69.0 & 100.0 \\
& Total & 100 & 100.0 & 100.0 & \\
\hline \hline
\end{tabular}

Source: Field Survey, 2019

\section{Conditions of Social Services}

Electricity: Figure 4 below shows that 66 or $66.0 \%$ of respondents stated that there is electricity supply in their communities while other 34 or $34.0 \%$ of the respondents answered in the negative.

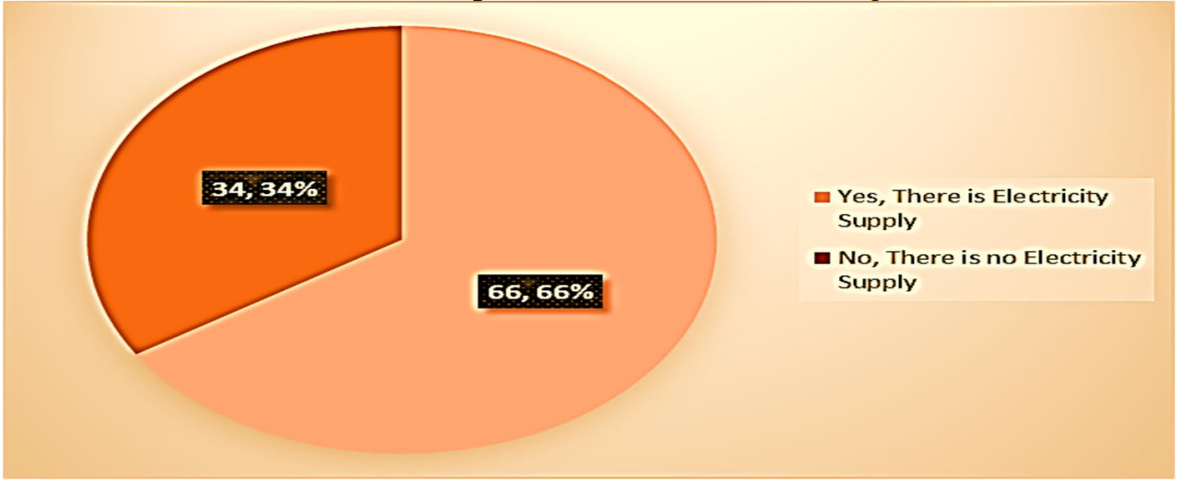

Figure 4: Pie Chart Showing Distribution of Responses on Supply of Electricity

Table 7: Regular Electricity Supply in Respondent's Community

\begin{tabular}{lllrrr}
\hline \hline & Frequency & Percent & Valid Percent & Cumulative Percent \\
\hline Valid & Very Irregular & 12 & 12.0 & 12.0 & 12.0 \\
& Somewhat Irregular & 39 & 39.0 & 39.0 & 51.0 \\
& Somewhat Regular & 15 & 15.0 & 15.0 & 66.0 \\
No Response & 34 & 34.0 & 34.0 & 100.0 \\
Total & 100 & 100.0 & 100.0 & \\
\hline \hline
\end{tabular}

Source: Field Survey, April 2019. 
Those respondents who stated that there is electricity supply in their communities claimed that its supply is irregular. As high as 39 or $39.0 \%$ of respondents said electricity supply is somewhat irregular, 15 or $15.0 \%$ of the respondents stated that it is somewhat irregular. Data on table 7 above and graphical distribution shown in figure 5 below underscores this fact.

Majority of the respondents 41 or $41.0 \%$ claimed indicated that electricity supply is not constant, while 6 or $6.0 \%$ of respondents claimed that there is constant electricity in their communities. The point of interest is that some communities have generating set provided by Local Government Councils. Graphical distribution shown in figure 7 below underscores this fact.

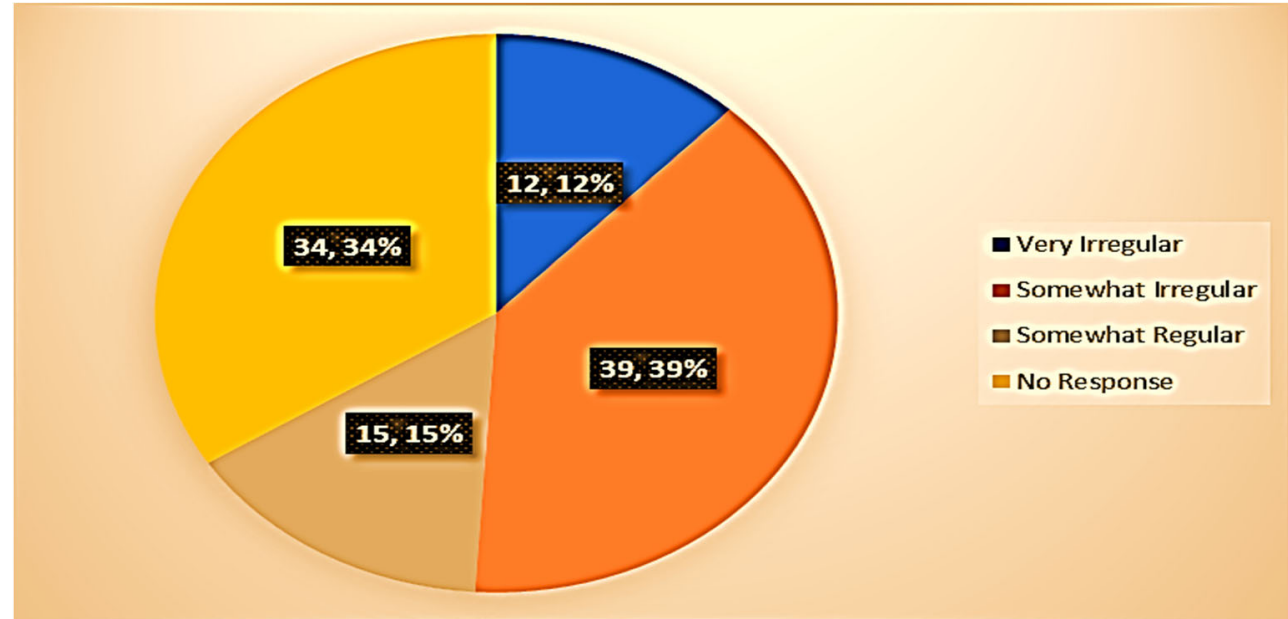

Figure 5: Pie Chart Showing Distribution of Respondents on Regularity of Electricity Supply

On the causes of irregular power supply, 19 or $19.0 \%$ and 5 or $5.0 \%$ of the respondents stated that the absence or irregular electricity supply could be traced to the absence or improper functioning of transformers and the problem of electric poles. Graphical distribution shown in Figure 6 above underscores this fact. Some of the most striking cases of neglect in the state are found in Uquo and Upenekan communities in Esit Eket and Ibeno Local Government Areas respectively. In spite of Ibeno having one of the most prolific fields in the Niger Delta, these towns are reputed for chronic levels of poverty, underdevelopment, and shanty communities.

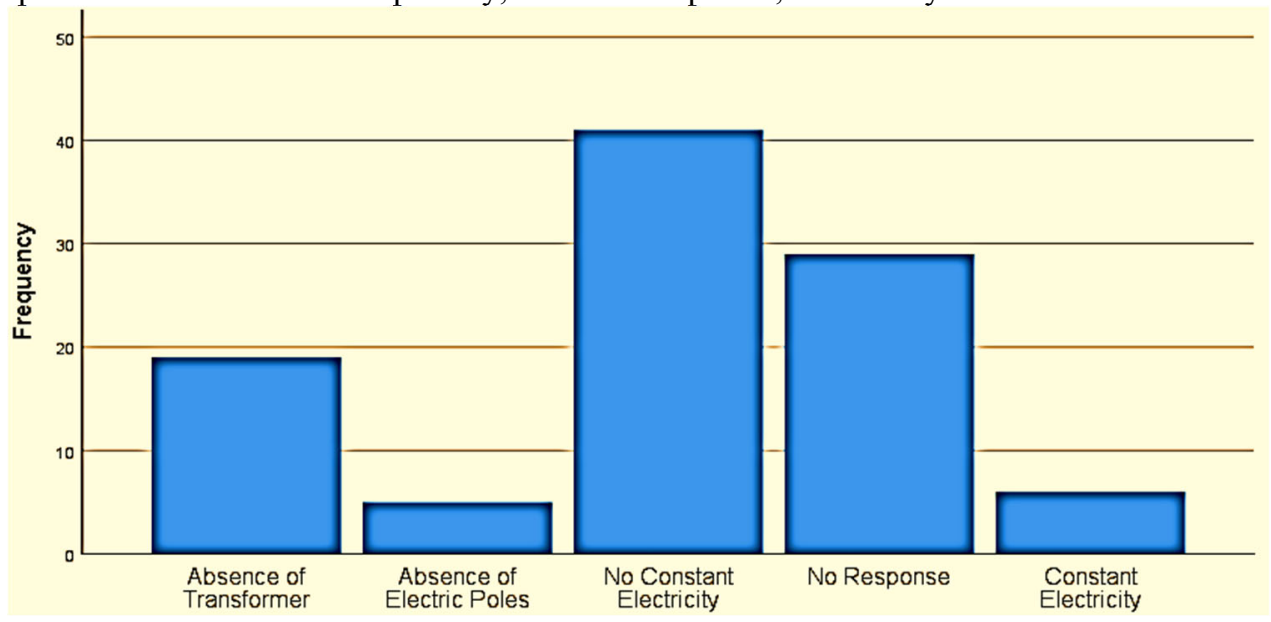

Figure 6: Distribution of Responses on Electricity Supply and Cause(s) of Irregular Power Supply

To test the reliability of the above response(s) the study sought to know the types of social services available in respondents' community/neighbourhood. 54 or $54 \%$ of respondents stated there is health delivery services while another 46 or $46.0 \%$ of respondents stated that there is none; 76 or $76.0 \%$ of the respondents stated there is lack of portable water while 24 or $24.0 \%$ other respondents said water is available; 50 or $50.0 \%$ of respondents claimed that electricity is available, while another 50 or $50.0 \%$ other respondents stated that it is not available. The study further revealed that the crisis of unemployment is real. 85 or $85 \%$ of the respondents stated that there is lack of employment opportunities, while as low as 15 or $15 \%$ of the respondents claimed that there are employment opportunities.

The study also revealed that there is high access to primary and secondary education in the state. 87 or $87 \%$ of respondents stated there is access to primary education; 13 or $13 \%$ of respondents indicated non-access; 58 or $58 \%$ other respondents stated there is access to secondary education while 42 or $42 \%$ of respondents stated there is lack of access to secondary education. Ibeno Local Government Area comprised of twenty-six villages and they 
all used Secondary Grammar School, Upenekang owned by the State Government. Students here sit on bare floor to learn. The situation appears to different with respect to access to Higher School Education as 81 or $81 \%$ of the respondents claimed lack of access to Higher School Education while another 19 or $19.1 \%$ of respondents indicated that there is access to Higher School Education. Similarly, 30 or $30 \%$ of respondents stated there is access to University Education while another 70 or $70 \%$ other respondents claimed lack of access to University Education. Data on table 8 below underscores this fact.

Table 8: Availability of Social Services in Communities/Neighbourhood of Respondents

\begin{tabular}{lcr}
\hline Social Services & Yes (\%) & No (\%) \\
\hline Health delivery & 54 & 46 \\
Potable water & 76 & 24 \\
Electricity provision & 50 & 50 \\
Employment opportunities & 85 & 15 \\
$-\quad$ State Government & 23 & 77 \\
- Local Government & 19 & 81 \\
- Oil Companies & 11 & 89 \\
Education facilities services & & \\
$-\quad$ Primary Education & 87 & 13 \\
$-\quad$ Secondary Education & 58 & 42 \\
- Higher Education & 81 & 19 \\
- University Education & 30 & 70 \\
Public transport facilities & 50 & 50 \\
\hline
\end{tabular}

Source: Field Survey, April 2019.

Potable drinking water and hospitals are in non-existence in Ibeno. The community has over ten abandoned water projects. There is no electricity. They are supplied water from Eket. Those who could not afford to buy the water from Eket, drink well water. The respondents rated the state low in terms of public transportation provisioning as 64 or $64 \%$ of the respondents said that transportation is not available while 36 or $36 \%$ of other respondents said it is available. With respect to employment opportunities, the response of the respondents showed that there is crisis of unemployment in the state. As low as 23 or $23 \%$ of respondents said there is access to state government employment opportunities; 77 or $77.0 \%$ of respondents' responded in the negative; 19 or $19 \%$ of respondents stated there is access to Local Government employment opportunities while an overwhelming majority of respondents ( 81 or $81.0 \%$ ) said there is lack of access. For the oil companies, 11 or $11 \%$ of respondents indicated there is access to oil companies' employment opportunities while as high as 89 or $89 \%$ of respondents claimed lack of access to employment opportunities by oil companies. There is absence of critical social investment in health care delivery by the State, Local Government and the Oil companies. Data on table 9 above underscores this fact. Ibeno communities have persistently been ravaged by crude oil spill for which the people have been denied the benefits in terms of $13 \%$ derivation.

To ascertain the consistency of the above responses, the study sought to know if there are some services or facilities the respondents do not have but would like to have? 84 or $84 \%$ of the respondents answered in the affirmative just as 16 or $16 \%$ other respondents said No. Graphical distribution shown in figure 7 below underscores this fact.

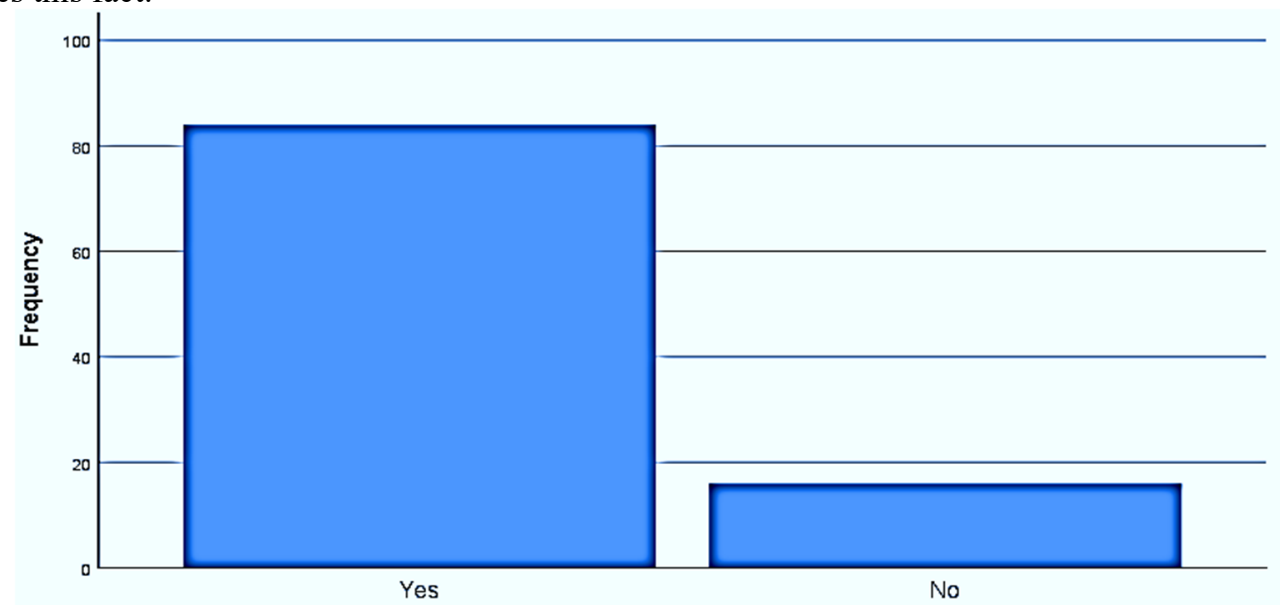

Figure 7: Showing Distribution of Responses on desirable Services and Facilities in their Communities Those respondents who stated 'Yes', listed the following services and facilities they would want to have in 
order of importance: Education, Portable Water, Electricity, Health Care and Employment opportunities. In a related development as high as 74 or $74.0 \%$ of respondents rated the State Government low in terms of provision of social services; 26 or $26.0 \%$ other respondents rated government good in this regard. Graphical distribution shown in figure 8 below underscores this fact.

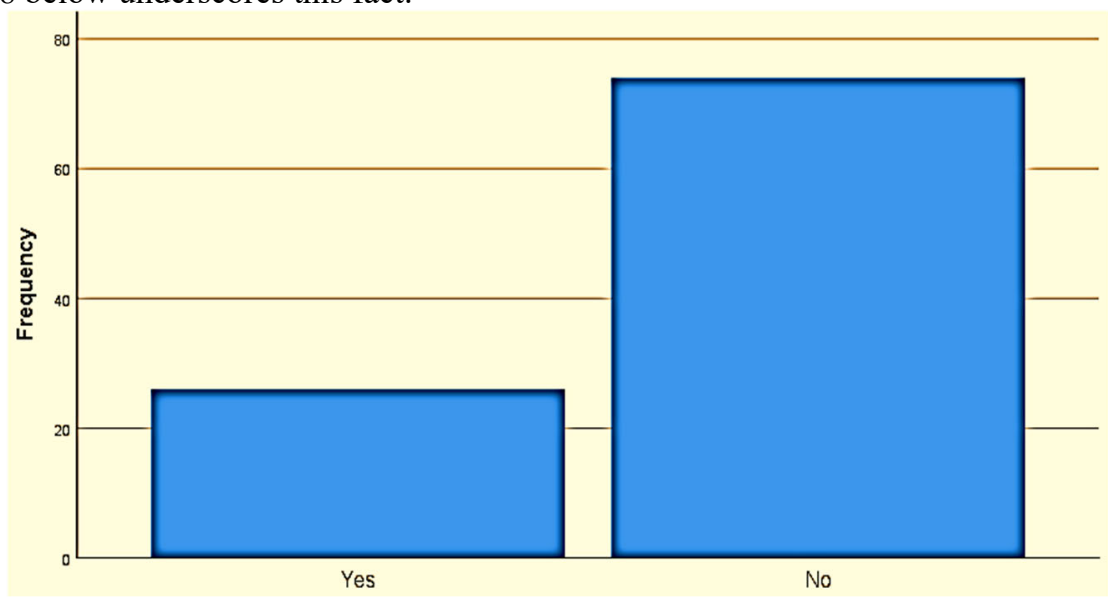

Figure 8: Bar Chart Showing Distribution of Responses on Rating of Government Good in Terms of Provision of Social Services

On the reason for their assessment; 11 or $11.0 \%$ of respondents stated that government promotes inequality, 37 or $37.0 \%$ of respondents indicated bad governance, another 26 or $26.0 \%$ chose corruption, 11 or $11.0 \%$ of the respondents stated no reason for their response. Graphical distribution shown in figure 9 below underscores this fact.

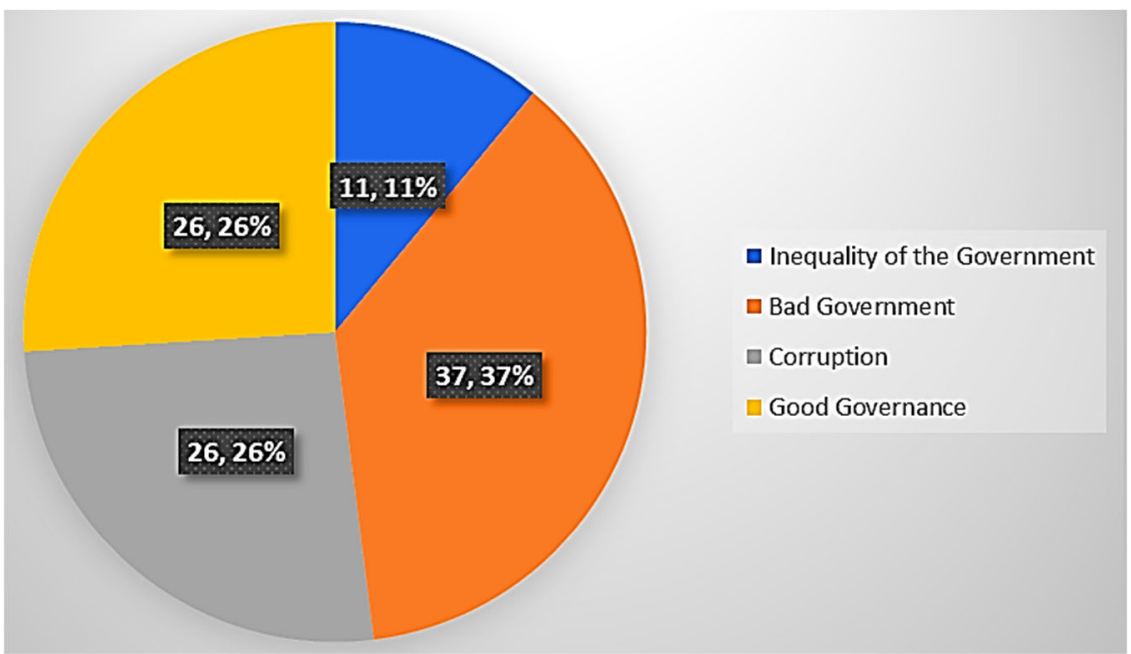

Figure 9: Distribution of Responses on Reasons for the Rating of Government

\section{Perception of Knowledge of $13 \%$ Derivation Fund}

Facts at the disposal of the researchers show that respondents seem to understand what derivation means. An overwhelming majority of the respondents (90 or $90.0 \%$ ) said it is that derivation permits a certain percentage of revenue derived from crude oil to be paid to the States in direct proportion of minerals extracted from the State. Furthermore, 10 or $10 \%$ other respondents stated that it is false. Similarly, a great majority of respondents (86 or $86 \%$ ) stated that it is True that it was for administrative purpose only that Derivation fund was routed through the state rather than communities. Also, 14 or $14 \%$ other respondents stated that it is false. Data on table 10 below underscores this fact.

Table 10: Perception on Knowledge of 13\% Derivation Fund

\begin{tabular}{lcc}
\hline Knowledge of $13 \%$ Derivation Fund & True (\%) & False (\%) \\
\hline $\begin{array}{l}\text { i). Derivation permits certain percentage of revenue derived from crude oil to } \\
\text { be paid to the States in direct proportion of minerals extracted from the State. }\end{array}$ & 90 \\
$\begin{array}{l}\text { ii). For administrative purpose only, derivation fund was routed through the state } \\
\text { rather than communities. }\end{array}$ & 86 & 10
\end{tabular}

Source: Field Survey, April 2019. 
On the remittance of the funds, 65 or $65 \%$ of the respondents indicated that the fund should be remitted directly to oil bearing communities instead of the State Government, 35 or 35.0\% of respondents hold the view that the derivation fund should be domiciled with the State Government. Graphical distribution shown in figure 10 below underscores this fact.

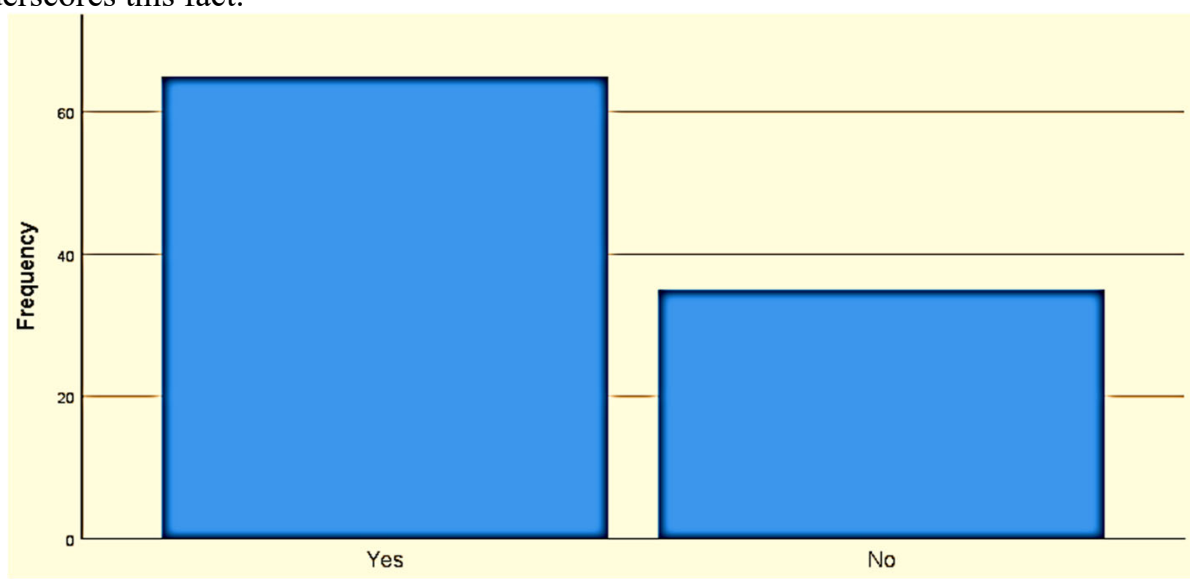

Figure 10: Distribution of Responses on Remittance of 13\% Derivation Fund to Oil Bearing Communities

Those respondents who want the $13 \%$ derivation fund to be remitted directly to oil bearing communities seem not to be very clear why this should be so. Also, 57 or $57 \%$ of respondents stated that Non accountability and misappropriation by the State government has become endemic; 43 or $43.0 \%$ other respondents stated No. 51 or $51.0 \%$ indicated that the $13 \%$ derivation fund is not part of the consolidated revenue of any tier of government; 49 or $49.0 \%$ of respondents answered in the negative; 47 or $47.0 \%$ stated that it underscores loss of faith and significant loss of faith between the oil bearing communities and the state government however, 53 or $53.0 \%$ of respondents stated otherwise, that is 'No'. Again, 48 or $48.0 \%$ of respondents stated that the derivation fund remains largely unnoticed in the oil bearing communities; other 52 or $52.0 \%$ of respondents disagreed with this view. Data on table 9 above underscores this fact. The foregoing responses create the impression that some community members do not understand the reasons for the call for direct remittance of the derivation fund directly to the communities rather than through the state government.

\section{Table 9: Responses to Reasons why FG should Pay 13 Derivation Directly to Communities Concerned}

\begin{tabular}{lcc}
\hline Reasons & $\begin{array}{c}\text { Yes } \\
(\%)\end{array}$ & $\begin{array}{c}\text { No } \\
(\%)\end{array}$ \\
\hline $\begin{array}{l}\text { i. Non-accountability and misappropriation has become endemic among state government } \\
\text { ii. } 13 \text { percent derivation fund is not part of the consolidated revenue of any tier of }\end{array}$ & 51 & 43 \\
government, whether Federal, State or local government, and has therefore, been illegally & 49 \\
appropriated by states to the detriment of oil bearing communities & 47 \\
iii). It underscores a loss faith and significant disconnect between state government and the & 53 \\
people of oil bearing communities \\
iv). The impact of the 13 percent derivation fund remains largely unnoticed in the oil \\
bearing communities which have continued to suffer neglect and deepening \\
impoverishment
\end{tabular}

Source: Field Survey, April 2019.

Some respondents think there is need for special agency, or commission to be established to manage the application of the 13 per cent derivation fund for oil producing communities in the state. Some elites especially those in Government reasoned that those calling for establishment should be careful about creating institutions because of its tendency to bureaucratize the functions of such institution. They argue that if such institution is created it will have need for offices, incur overhead cost, need capital and logistics to run the offices, and the money that will be use in servicing the bureaucracy will be a subtraction for the amount of money that will be available to the state. This school of thought reasoned that what the state really need is a transparent budgeting system that everybody will know that this is the money we have, how it was spent and be able to follow through. Against this backdrop, the call for direct remittance seems an elite driven agenda or ineffective sensitization of the grassroots on the benefit of resource governance institution. This situation notwithstanding, it came out strongly that the agitation for resource control by inhabitants of the oil bearing will continue, despite the constitutional provision that increased derivation from the paltry $3 \%$ in 1992 to the present $13 \%$. Why this will be so, can be seen on the table 10 below. 
Table 10: Reason for Continuous Agitation for Resource Control Despite Provision for Derivation in Constitution and Increment from 3\% in 1992

\begin{tabular}{llcccr}
\hline \hline & & Frequency & Percent & Valid Percent & Cumulative Percent \\
\hline Valid & No Response & 15 & 15.0 & 15.0 & 15.0 \\
& Government Deprivation/Neglect & 15 & 15.0 & 15.0 & 30.0 \\
& Corruption & 70 & 70.0 & 70.0 & 100.0 \\
& Total & 100 & 100.0 & 100.0 & \\
\hline \hline
\end{tabular}

Source: Field Survey, April 2019.

Akwa Ibom State is yet to established by law any or organization to receive and to administer exclusively $13 \%$ oil derivation fund accruing to the state even though the State is an oil producing state. Data on table 10 shows that agitation for resource control will continue due to corruption (70 or $70.0 \%)$ and perceived government deprivation/neglect $(15$ or $15 \%)$

Perceptions of the Most Beneficial Effects of the Present Administration in the State

To assess the effects of the present administration in the state, the study posed the question is there any government presence in your community? In response, 34 or $34.0 \%$ of respondents stated yes; 66 or $66.0 \%$ other respondents said No. Graphical distribution shown in figure 11 below underscores this fact.

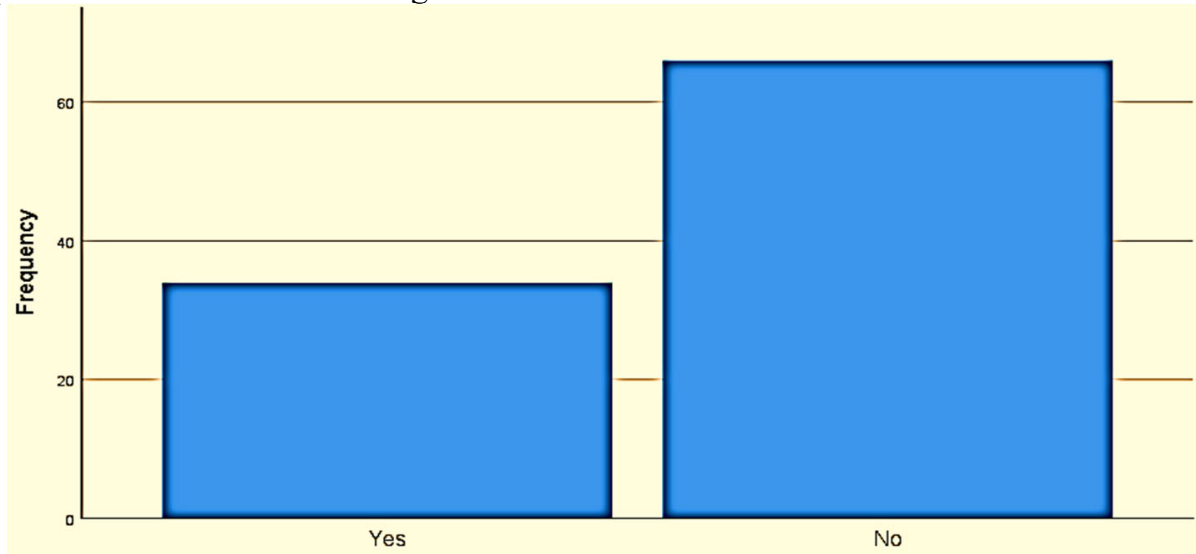

Figure 11: Bar Chart Showing Distribution of Responses on Government Presence in Communities

When asked to state the most beneficial effects of the present administration in order of importance, the response of the respondents showed that that the present administration had made progress in the following areas: improvement of local agriculture (17 or $17.0 \%$ ), increased opportunity for small scale business to spring up (15 or $15.0 \%$ ), and opportunities to execute contracts (14 or $14.0 \%)$. These are followed closely by increased employment opportunity for local populace (11 or $11.0 \%$ ), scholarship for training of youth (11 or $11.0 \%$ ); welfare programme for the Community (10 or $10.0 \%)$ and increased revenue to government in the form of tax ( 8 or $8.0 \%)$. Data on table 11 below underscores this fact.

Table 11: Responses on Most Beneficial Effects of the Present Administration In order of Importance

\begin{tabular}{lr}
\hline Reasons & Yes (\%) \\
\hline i. Improvement of Local Agriculture & 17 \\
ii. Increased Opportunity for Small Scale Business to Spring Up & 15 \\
iii. Opportunities to Execute Contracts & 14 \\
iv. Increased Employment Opportunity for Local Populace & 11 \\
v. Scholarship for Training of Youth & 11 \\
vi. Welfare Programme for the Community & 10 \\
vii. Increased Revenue to Government in the form of Tax & 8 \\
\hline
\end{tabular}

Source: Field Survey, April 2019.

\section{Rating of Government's Performance with reference to some aspects of Sustainable Development}

In Table 12, 52 or $52.0 \%$ of the respondents stated they are very satisfied with government's performance on provision of scholarship for training of youth and women; 10 or $10 \%$ other respondents indicated they are satisfied; 37 or $37.0 \%$ of respondents claimed Do not know/Uncertain; while only 1 or $1.0 \%$ other respondents stated they are very satisfied. A relatively high percentage of respondents: 53 or $53.0 \%$ stated they very unsatisfied with the provision of infrastructural facilities; another 28 or $28.0 \%$ of respondents indicated they satisfied, 1 or $1.0 \%$ of respondents stated it is very satisfactory; 18 or $18.0 \%$ of respondents indicated that they do not know. With respect to provision of employment opportunities for indigenes of host communities, as high as 54 or $54.0 \%$ of the 
respondents said it is very unsatisfactory, 18 or $18.0 \%$ of respondents stated is satisfactory; while 28 or $28.0 \%$ other respondents stated they Don't know/Uncertain. In a similar vein, 53 or $35.0 \%$ of the respondents indicated they are very unsatisfied the provision of opportunities for contract work; interestingly, 17 or $17.0 \%$ of respondents stated they are satisfied; another 1 or $1.0 \%$ of respondent is very satisfied, and 29 or $29.0 \%$ of respondents claimed they Do not know/Uncertain. With respect to improvement of local agriculture, most of the respondents stated they are very unsatisfied with government's performance. 53 or $53 \%$ of the respondents stated very unsatisfactory. Interestingly, 25 or $25.0 \%$ of respondents indicated they are satisfied, 3 or $3.0 \%$ of respondents stated very satisfied, while 19 or $19.0 \%$ stated they Do not know/Uncertain.

The trend does not seem to change with respect to government's aiding of small scale industry: 54 or $54.0 \%$ of respondents claimed that government's effort in this regard is very unsatisfactory; 12 or $12.0 \%$ other respondents indicated satisfactory; 2 or $2.0 \%$ of respondents stated very satisfactory while as high as 32 or $32.0 \%$ of respondents they Don't Know/Uncertain. Although the State government claimed to be women sensitive, facts at disposal of this assessment proved otherwise. Also, 45 or $45 \%$ of the respondents rated government's effort as per Women Development Programmes Very Unsatisfactory, 21 or 21,0\% of respondents rated it Satisfactory, 34 or $34.0 \%$ other respondent claimed they Do not know/Uncertain. The same unsatisfactory faith befell Youth Development Programmes in the State. 49 or $49.0 \%$ of the respondents stated that the youth development programmes are Very Unsatisfactory, 18 or $18.0 \%$ of respondents stated they are Satisfactory while as high as 33 or $33.0 \%$ other respondents claimed that they do not know or are Uncertain.

Table 12: Rating the Performance of the Present Administration in Terms of Welfare of Community/Neighbourhood

\begin{tabular}{lcccc}
\hline Sustainable Development Indicators & VU (\%) & S (\%) & DK/U (\%) & VS (\%) \\
\hline i. Provision of scholarships for training of youth and women & 52 & 10 & 37 & 1 \\
ii. Provision of infrastructural facilities & 53 & 28 & 18 & 1 \\
iii. Provision of employment opportunities for indigenes of host & 54 & 18 & 28 & 0 \\
iv. Provision of opportunities for contract work & 53 & 17 & 29 & 1 \\
v. Improvement of local agriculture & 53 & 25 & 19 & 3 \\
vi. Aiding small -scale industry & 54 & 12 & 32 & 2 \\
vii. Women Development Programmes & 45 & 21 & 34 & 0 \\
viii. Youth Development Programmes & 49 & 18 & 33 & 0 \\
\hline
\end{tabular}

Source: Field Survey, April 2019.

(NB: VU = Very Unsatisfactory, S = Satisfactory, DK/U = Don't Know/Uncertain, VS = Very Satisfactory)

Against the above backdrop, the study posed the question asking: 'Everything considered, how please or displeased are you with the present administration'? Answer to this question seems to corroborate the findings above. For instance, 32 or $32.0 \%$ of the respondents stated they are very Displeased, 16 or $16.0 \%$ of respondents indicated they are Somewhat Displeased, 26 or $26.0 \%$ of respondents claimed they are Neither Pleased nor Displeased, 20 or $20.0 \%$ of the respondents stated they are Somewhat Pleased; a very negligible 4 or $4.0 \%$ of respondents stated they are Very Pleased while 2 or $2.0 \%$ of respondents indicated No Response. Graphical distribution shown in figure 12 below underscores this fact.

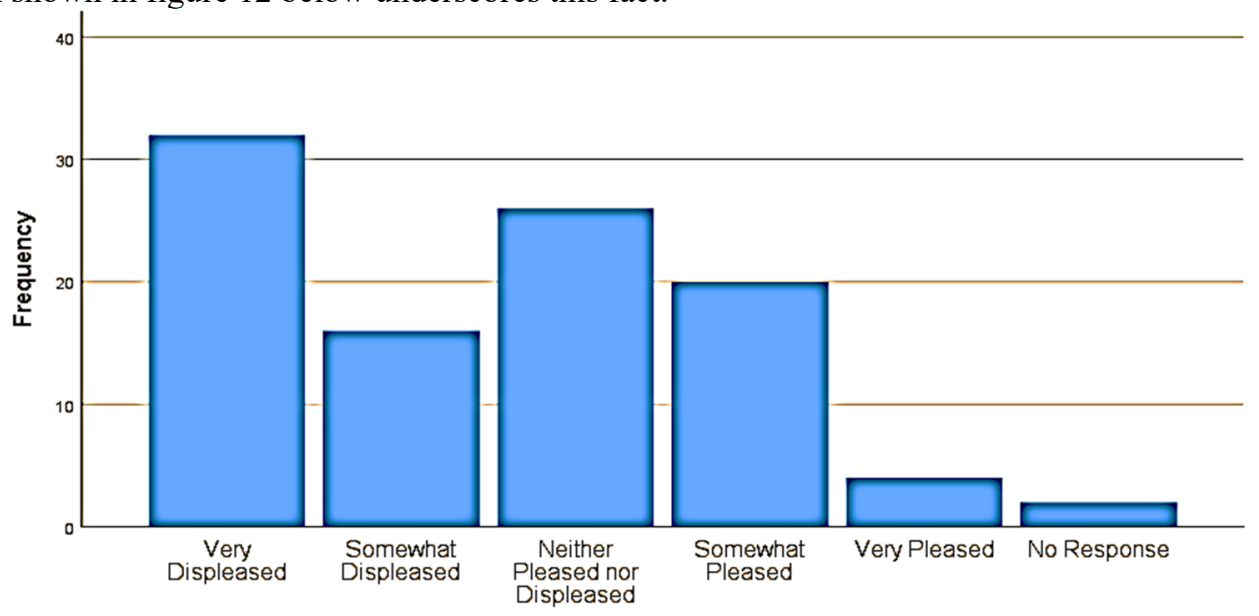

Figure 12: Bar Chart Showing Distribution of Responses on How Pleased Respondents Are With Present Administration

Some of the reasons for the respondents' displeasure with the Government derived from the Poor state of Social Services such as Health Care; Education; lack of Portable water; Unemployment and Poor State of Infrastructure. The point of interest is that an overwhelming majority of the respondents (98 or $98.0 \%)$ stated they have High expectations that the Government will do better while 2 or $2.0 \%$ of the respondents do not expect that 
Government will change the situation for better days ahead (See Figure 13). This should not be a surprise because Akwa Ibom State appeared to the most prudent, as its recurrent expenditure profile only $25 \%, 31 \%, 47 \%, 57 \%$ and $52 \%$ of its total revenue from 2012 to 2016 respectively was expended on recurrent expenditure. The State's Capital Expenditure is as follows: 2012 (281,868); 2013 (264,632); 2014 (194,573); 2015 (114,415); 2016 $(92,306)$, making a total of 138,668 (NEITI, 2019). The 2017 budget showed parity between recurrent and capital expenditure. This is interesting because increase in recurrent expenditure will negatively impact available funds for capital expenditure thereby denying the citizens the much needed infrastructure for development of the State.

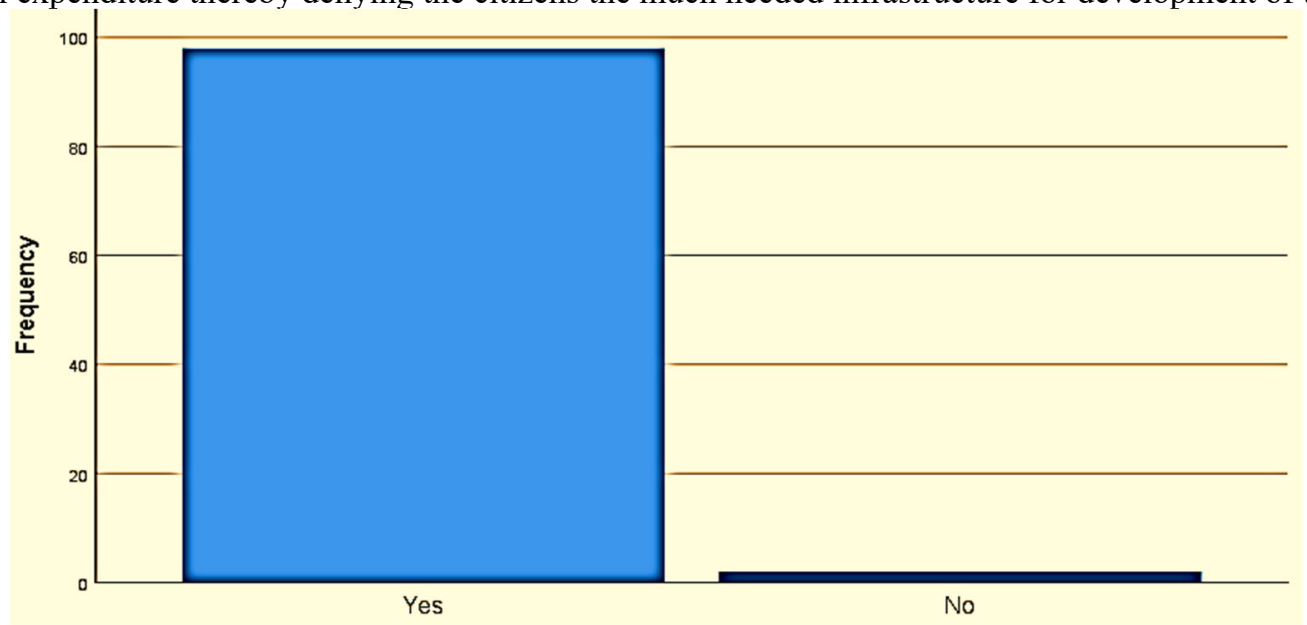

Figure 13: Bar Chart Showing Distribution of Responses on Expectations from Government.

\section{Discussion of Findings}

Akwa Ibom state received the highest share of federal allocation in 2017 , based on the payment of $13 \%$ of petroleum revenues to the states of derivation. Unfortunately, the State has acquired a tradition of embarking on expensive /prestigious projects or what some respondents termed "elephant projects" with limited benefits for its poor inhabitants. According to Nigeria Extractive Industries Transparency Initiative (NEITI), Akwa Ibom state received the sum of N143.6 in 2017 from the Federation Account, reflective of improved global crude oil prices. Unfortunately, since the statutory receipts could not finance the entire budget for the same year, Government of the resorted to opaque loans during the year (Social Action, 2017).

Although some respondents' resident in Uyo, the State capital stated Government, has made some progress in addressing some of the nagging problems of development, it really not in the dimension envisaged by the people of the states especially, those from the oil producing areas against the backdrop of the huge revenue which accrued to the State from $13 \%$ derivation fund. Data at the disposal of the study revealed that vital sectors such as education, health, electricity supply, pipe borne water and employment generation were below expectations of inhabitants of the Oil Producing Areas. It came out strongly from special interviews that part of the problem of "Low performance or service delivery" could be traced to poor management of oil derivation in particular and public finance in general. This, they claimed, compounded the impoverishment of the citizens as the State continue to be characterized by wide spread poverty, low employment rate, inadequate infrastructure and social services.

Some government officials who spoke to the research team on condition of anonymity stated that the stated under the present administration of appeared to be a departure from the last administration even though they are from the same political party from development trends of the State with visible renovation and construction of schools and hospitals and other infrastructure, inhabitants of the oil producing areas argue that government's effort at social services and infrastructure provisioning are with less focus on their communities. Data at the disposal of the study showed that the state of development of physical infrastructure does not march the revenue profile of the state. Despite the fact that elite of the oil producing communities claimed that government have awarded contracts for some projects, some of the respondents stated that the contracts "were tied to a patronage system especially during the just concluded political electioneering period.

General perception of inhabitants of the non-oil producing areas is that the 13 per cent does not come separately or tailor-made for only oil producing areas of the state, but it is captured in the state -wide budget and used for the development of the whole state. This implies that the affected people are not benefiting from the 13 per cent derivation fund because of the elite economy in place. The elite are just sharing the money and all the benefits that should accrue to the people of the oil producing communities who are left in the cold.

Although the 2017 budget of the State achieved a relative parity between recurrent and capital expenditures; however, close perusal of the budget shows that actual budget implementation was skewed in favour of re-current spending. For example, education and health got $2.4 \%$ and $1.6 \%$ respectively in the budget. The poor allocation to these crucial sector, according to Social Action (2017), may not be surprise considering that top politicians and 
policy makers in the State often travel abroad for medical treatment and also send their children to expensive private schools within Nigeria and abroad. Worse still, despite the small allocations to education and health sectors, it was found that projects in the budget are mostly unexecuted.

For example, like projects in the educational and health sectors, projects approved for the agricultural sector were at most partially executed. In fact, some projects were not even carried out. This is the case with the Small Ruminant Project with was designed to construct 2 No. Standard Goat Houses and Establishment of 2 ha Goat Browsing Paddocks at Adadia, in Uruan for which N5.95m, procurement of 200 WAD Goats for farms at Adadia, Uruan and Distribution to participants of Small Holders Scheme - N2.7m, Provision for Supplementary Feeds, Drugs/Vaccines for N1.35m. Although the sum of N10 million was allocated to the project in 2016 fiscal year, the project also got another N10 million in 2017 yet members of the beneficiary communities claimed not to be aware of the project. The point to note is that

"the level of investment of a State in its Economic, Educational and Social sectors directly impacts the State's overall growth and development by improving investors' confidence and private sector participation in the development of the State. The standard of living of its people would also increase through job creation and intellectual property development" (NEITI, 2019: 24).

Akwa Ibom State, unlike Delta, Edo and Ondo States, is yet established an agency of a commission to that will be statutorily charged with the development of her oil producing communities. Some elites in government felt that the quantum of oil produced in the state is not much to warrant establishment of an institution or agency to administer the $13 \%$ derivation fund due the State. This should not be a surprise because the study here revealed that majority of the respondents knows little about $13 \%$ derivation. Yet, efforts to fast-track the development of the region particularly, the oil and gas producing communities has led to the setting up of Agencies, Commissions and a Ministry as a direct response to growing agitation of indigenes of the area who many years suffered deprivation and neglect from government. Few will question nowadays, the critical role institutions, institution building and institutional reforms play in the process of economic and social development. Institutions and development interact in a two-way relationship such that institutions can help accelerate the rate of economic development, while the latter may trigger institutional reforms.

There are several perspectives to the definition of institution. Rains (1989) observed that institutions define how people inhabiting a certain landscape and having command over given resources decide to organize themselves for economic activity. Institutions may also be seen as "a set of structures, lasting patterns of behaviours and relationships(roles) that are guided and supported by broad societal values, regulated by certain norms of conduct(rules) and operationalized by organizations" (Dia: 1996). For North (1991), institutions are the humanly devised constraints that structure political, economic and social interaction; while the World Bank, (2002) defined institutions to refer to rules, enforcement mechanisms, and organizations.

This debate must not detain us here however; it is important to emphasize that institutions are contextsensitive. Hence, it is often sensible for each country, state or region to develop its own institutions. Different social contexts, conditions and leaderships yield vastly different outcomes for the same type of institutions. Each country's historical and cultural heritage constitutes an important factor in the evolution and transformation of its institutions. While institutions and governance are legitimate areas of concern for effective utilization of $13 \%$ derivation fund for the benefit of Oil and Gas producing areas, the study contends that these institutions can quickly be turned into predatory organs riddled with corruption, mismanagement, ineffectiveness and inefficiency if the people fail to monitor their activities and operations regularly.

Participants in the Special Interview opined that building appropriate and effective institutions is fundamental to good governance and improvement of the existential conditions of inhabitants of the oil and gas producing areas. There is thus an urgent need to institutionalize the management of $13 \%$ derivation fund in the State through a legal framework that will enthrone equity and transparency, create awareness of its existence, and build capacity of citizens to monitor the activities of such institution. It is also necessary that the State government design socioeconomic development plans, projects and programmes that are capable of creating employment and socially equitable sustainable development in the oil and gas producing areas in particular and the State in general.

Food production capacity of the communities and income generation from agriculture and fishing of the communities is significantly threatened as a result of crude oil production activities. Consequently, it is important that government pays attention to food security and sustainable agriculture. Food security exists when all people, at all times, have physical and economic access to sufficient, safe and nutritious food to meet their dietary needs and food preferences for an active and healthy life. Energy is essential to all human activities. In fact, it is inevitable for poverty alleviation and the production of goods and services. Over $70 \%$ of the respondents live without access to electricity. Energy demand in the study area is dominated by the use of wood as fuel.

\section{Conclusion and Recommendations}

The relevant question and development policy issue the study raises is no longer "Do institutions matter?" in 
effective and efficient use of $13 \%$ derivation fund? But "which institution(s) will be more effective and efficient for the development of the Oil Producing Areas, and how do governments of the Niger Delta build and nurture such institution(s) and address the resource management question pointedly? a strong, effective and efficient oil revenue governance institution(s) is/are called for to manage the use of $13 \%$ derivation fund. Getting the institutions right is critical for supply of electricity, health, portable water, food, education and environmental protection. However, if the institution(s) are vulnerable to the problem of the State in Nigeria especially, corruption, they will be fatal to sustainable community development. It is common knowledge that in Nigeria, bureaucracies are prone to two problems: they can be captured by the interests they are supposed to defend; they also create extreme red-tapism which discourages economic activities. Consequently, the focus should not just be about creating institutions because the effectiveness of these institutions is largely a function of their degree of independence and professionalism.

While economic and democratic governance are legitimate areas of concern for the sustainable development of community people, they must be cast within the broader context of the need to build strong effective institutions of political governance. To improve governance, Akwa Ibom State needs to lay more emphasis on decentralization and devolution of power. The pervasive weakness of Local Government Councils and lack of capacity for them is a case in point. It is against this backdrop that the study put forward the following recommendations:

1. There is an urgent need for the State Government to establish and manage an effective and transparent institution that will use the $13 \%$ derivation fund to the benefit of the people.

2. The Government should address more vigorously, the issue of service delivery, transparency and accountability in public service

3. Cultivate and nurture an environment that will accelerate poverty reduction and enthrone sustainable development.

4. To play an active role in enthroning good governance, civil society has to emerge as a strong voice in the development process. This implies that it has to play a vital role in mobilizing the citizens to pressure government to establish $13 \%$ derivation fund institution, articulating social demands for its use and providing countervailing influences to elicit accountable performance and transparency in the use of derivation fund.

\section{References}

African Network for Environment and Economic Justice (ANEEJ) 2008. An Independent Civil Society Analysis of Edo State Oil and Gas Producing Areas Development Commission (EDSOGPADEC) 2007-2008 Budget and Expenditure. November 2008, Benin City.

African Network for Environment and Economic Justice (ANEEJ) and Leadership Initiative for Transformation and Empowerment (LITE-Africa) 2016. Improving Effectiveness of Federal Ministry of Niger Delta Affairs.

African Network for Environment and Economic Justice (ANEEJ) and Leadership Initiative for Transformation and Empowerment (LITE-Africa) 2016. Improving Effectiveness of Niger Delta Development Commission (NDDC).

African Network for Environment and Economic Justice (ANEEJ). 2015. Coping with Oil Price Shocks. A Civil Society Perspective, Benin City.

African Network for Environmental and Economic Justice (ANEEJ) and Leadership Initiative for Transformation and Empowerment(lite-Africa) 2016. Improving Effectiveness of Delta State Oil Producing Areas Development Commission.

Alca'ntara, C.H., 1998, Uses and abuses of the concept of governance. ISSJ 155/1998, UNESCO Published by Blackwell, publishers, Oxford, UK and USA.

Dia, M. 1996. Africa's Management in the 1990s and Beyond: Reconciling Indigenous and Transplanted Institutions, Washington DC: The World Bank.

Ebiri, K. 2019. Oil Producing Communities Reek of Poverty Over N10t 13\% Derivation Fund. Cover, The GUARDIAN, Sunday, November 17, 2019. Isolo-Lagos.

Ibibio Ethnic Nationality. 2008. Memorandum submitted to the Technical Committee on the Niger Delta. Report of the Technical Committee on Niger Delta (RTCND), Vol. 2. Abuja, Nigeria.

Joab-Peterside, S. 2018. Fiscal Federalism and Agitations for Resource Control in Nigeria: A South-South Perspective. Research on Humanities and Social Sciences. Vol. 8 No. 16. International Institute for Science, Technology \& Education. Accelerating Global Knowledge Creation and Sharing. New York and London.

Naanen, B. 2019. 13\% Derivation is A Constitutional Failure. Cover, The GUARDIAN, Sunday, November 17, 2019. Isolo-Lagos.

Nigeria Extractive Industries Transparency Initiative(NEITI), 2019. Revenues, Deductions, Analysis of Disbursement of Funds by Selected State Government. Abuja, Nigeria.

Nigeria Institute of Management (NIM), 2008. Memorandum submitted to the Technical Committee on the Niger Delta. Report of the Technical Committee on Niger Delta(RTCND), Vol. 2. Abuja, Nigeria. 
North, D. C. 1991 Institutions. Journal of Economic Perspective.

Onwioduokit, E. 2019. Let People Demand Accountability from Their Government. Cover, The GUARDIAN, Sunday, November 17, 2019. Isolo-Lagos.

Rains, G. 1989. The Role of Institutions in Transition Growth: The East Asian Newly Industrializing Countries. World Development, Vol. 17 N0.9.

Social Development Integrated Centre (Social Action) 2017. Abandoned Projects- Citizens' Report on Budgets of Selected States of Nigeria, 2017. Port Harcourt.

Spiff, D. S. 2007. Legal Mechanism for the Resolution of the Niger Delta Crisis. Paper presented at the Annual Business Law Conference of the Section on Business Law, Nigeria bar Association Abuja, 11-14 ${ }^{\text {th }}$ March, 2007.

Stoker, G. 1998. Governance as Theory: Five propositions, ISSJ/1998, UNESCO. Blackwell Publishers, Oxford, UK and USA.

The Guardian, 2013. Editorial: Oil Communities and Derivation Proceeds. Sunday, January 20, 2013, Lagos, Nigeria.

United Nations Development Programme(UNDP). 2006. Niger Delta Human Development Report, Abuja: United Nations Development Programme.

Wohlmuth, K., 1999, Good Governance and Economic Development in Africa, in African Development Perspectives, Year Book 1997/98: Good Governance and Economic Development, Wohlmuth, K.; Bass, H.H.; Messner, F; (eds). Transactions Publisher, New Brunswick(USA) and London(U.K.).

Wohlmuth, K.; Bass, H.H.; Messner, F; (eds),1999, African Development Perspectives, Year Book 1997/98: Good Governance and Economic Development, Transactions Publisher, New Brunswick(USA) and London(U.K.)

World Bank, 2002. Building Institutions for Markets, New York and N Y: Oxford. 